\title{
Identifying various type of Pathologies in Magnetic Resonance (MR) Image using Jaya algorithm
}

\author{
Mr.A.Saravanan \\ Assistant Professor,Department of \\ Computer science and Engineering \\ Kalasalingam Academy of Research \\ and Education \\ Anand Nagar, Krishnankoil, \\ Tamilnadu,India. \\ a.saravanan@klu.ac.in \\ S.Lakshmi Narayani \\ Department of Computer science and \\ Engineering \\ Kalasalingam Academy of Research \\ and Education \\ Anand Nagar,Krishnankoil, \\ Tamilnadu, India. \\ lakshmi.narayani04@gmail.com
}

S.Anushiya

Department of Computer science and Engineering

Kalasalingam Academy of Research and Education

Anand Nagar, Krishnankoil,

Tamilnadu ,India

anushiyasekar.as@gmail.com
G.Kodieswari

Department of Computer science and Engineering

Kalasalingam Academy of Research and Education

Anand Nagar, Krishnankoil,

Tamilnadu,India

kodieswari96@gmail.com

Abstract-Tumor diagnosis play a significant role in the medical field. The task of identifying the tumor leads to more critical because of more complexity in the structure and size of the cancer cell. The recommended Jaya algorithm can be used for clustering and produced improved result in segmenting the tumor region. Jaya algorithm produces optimal solution for constrained problem by identifying the best and worst solution for all subset. If the solution provided is better than the previous one then the new one is updated otherwise it will take the previous one for consideration. These techniques delivered a prominent result for tumor having different boundaries and complex structures. The results obtained from jaya algorithm are compared with conventional algorithm like particle swarm optimization (PSO) clearly shows quite improved that can be used to identify various pathologies in magnetic resonance (MR) image.

Keywords-Particle Swarm Optimization (PSO), Jaya clustering, Magnetic Resonance Image (MRI).

\section{INTRODUCTION}

The tumor grade can be mentioned based on the grade.If the tumor is diagnosed as malignant then immediate care should be done for the patients. Another benign type of tumor can spread slowly and it is also called as low risk grade type. But the malignant type is high risk grade type of tumor. The recommended Jaya algorithm is used to identify the various types of tumors with different structure and with different grades. This technique will help the surgeon to recognize the tumor with different shapes and to perform the segmentation in quick duration. The Jaya algorithm is used to perform better clustering than the conventional techniques. By identifying the best and worst solutions. Finally the optimal solution is attained by these techniques. The decision can be made better and more exact by incorporating the jaya algorithm to the segmentation process.

\section{RELATED WORKS}

\begin{tabular}{|l|l|l|l|l|}
\hline $\begin{array}{l}\text { S. } \\
\text { N }\end{array}$ & $\begin{array}{l}\text { Author's } \\
\text { Detail }\end{array}$ & $\begin{array}{l}\text { Proposed } \\
\text { techniques/utilize } \\
\text { d methodology }\end{array}$ & $\begin{array}{l}\text { Benefits of the } \\
\text { proposed } \\
\text { methodology/alg } \\
\text { orithm }\end{array}$ & $\begin{array}{l}\text { Demerits of the } \\
\text { techniques }\end{array}$ \\
\hline 1. & $\begin{array}{l}\text { Rupali S. } \\
\text { Kamathea } \\
\text { et al } \\
(2018)\end{array}$ & $\begin{array}{l}\text { A novel } \\
\text { technique is } \\
\text { developed for } \\
\text { demarcating } \\
\text { the gray and } \\
\text { white matter } \\
\text { in MRI. }\end{array}$ & $\begin{array}{l}\text { Alzheimer } \\
\text { type } \\
\text { pathology of } \\
\text { identified by } \\
\text { the } \\
\text { recommended } \\
\text { techniques }\end{array}$ & $\begin{array}{l}\text { The Alzheimer } \\
\text { on } \\
\text { type of } \\
\text { pathology. }\end{array}$ \\
\hline
\end{tabular}

\begin{tabular}{|c|c|c|c|c|}
\hline 2. & $\begin{array}{l}\text { Alexis } \\
\text { Arnaud et } \\
\text { al (2018) } \\
{[1] .}\end{array}$ & $\begin{array}{l}\text { Lesion in } \\
\text { MRI can be } \\
\text { identified by } \\
\text { the suggested } \\
\text { techniques. }\end{array}$ & $\begin{array}{l}\text { Different } \\
\text { types } \\
\text { lesions } \\
\text { located in the } \\
\text { image can be } \\
\text { identified by } \\
\text { the suggested } \\
\text { techniques }\end{array}$ & $\begin{array}{l}\text { The similarity } \\
\text { index } \\
\text { obtained by } \\
\text { the techniques } \\
\text { can be } \\
\text { improved to } \\
\text { higher level. }\end{array}$ \\
\hline 3. & $\begin{array}{l}\text { Saravanan } \\
\text { Alagarsa } \\
\text { my et al } \\
(2017) \\
{[12] .}\end{array}$ & $\begin{array}{l}\text { The author } \\
\text { used the } \\
\text { feature of } \\
\text { cuckoo for } \\
\text { search and } \\
\text { clustering is } \\
\text { done by fuzzy } \\
\text { for } \\
\text { segmentation. }\end{array}$ & $\begin{array}{l}\text { Different type } \\
\text { of tumors is } \\
\text { located in } \\
\text { MRI by the } \\
\text { suggested } \\
\text { technique. }\end{array}$ & $\begin{array}{l}\text { The } \\
\text { validation } \\
\text { process can } \\
\text { be extended } \\
\text { towards for } \\
\text { more number } \\
\text { of images. }\end{array}$ \\
\hline 4. & $\begin{array}{l}\text { Angulaks } \\
\text { hmi M et } \\
\text { al (2018) } \\
{[11] .}\end{array}$ & $\begin{array}{l}\text { Spectral } \\
\text { Clustering } \\
\text { techniques is } \\
\text { used by the } \\
\text { authors }\end{array}$ & $\begin{array}{l}\text { Edema } \\
\text { portion are } \\
\text { precisely } \\
\text { segmented }\end{array}$ & $\begin{array}{l}\text { The } \\
\text { validations } \\
\text { can be done } \\
\text { with more } \\
\text { number of } \\
\text { images. }\end{array}$ \\
\hline 5. & $\begin{array}{l}\text { Govindara } \\
\text { j et al } \\
(2014) \\
{[16] .}\end{array}$ & $\begin{array}{l}\text { Fuzzy C- } \\
\text { means } \\
\text { techniques is } \\
\text { used by the }\end{array}$ & $\begin{array}{l}\text { The proposed } \\
\text { algorithm } \\
\text { located the } \\
\text { tumors in }\end{array}$ & $\begin{array}{l}\text { The elapsed } \\
\text { time for } \\
\text { performing } \\
\text { the }\end{array}$ \\
\hline
\end{tabular}




\begin{tabular}{|l|l|l|l|}
\hline & authors & $\begin{array}{l}\text { different axes } \\
\text { of image are } \\
\text { used }\end{array}$ & $\begin{array}{l}\text { segmentation } \\
\text { can be } \\
\text { reduced }\end{array}$ \\
\hline
\end{tabular}

\section{PROPOSED METHODOLOGY}

\section{A. JAYA ALGORITHM}

Jaya is mainly used to solve optimization problems based on the population oriented. It produces optimal solution for the unconstrained problems. The idea of this technique is to find the optimal solution for the specific problems.

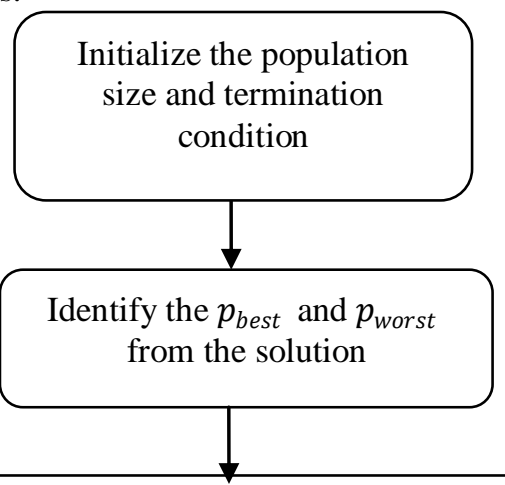

Updating of best and worst solution in membership function $p_{j, k, i}=p_{j, k, i}+r_{1, k, i}\left(p_{j, \text { best }, i^{-}}\left|p_{j, k, i}\right|\right)-r_{2, k, i}\left(p_{j, \text { worst }, i^{-}}\left|p_{j, k, i}\right|\right)$

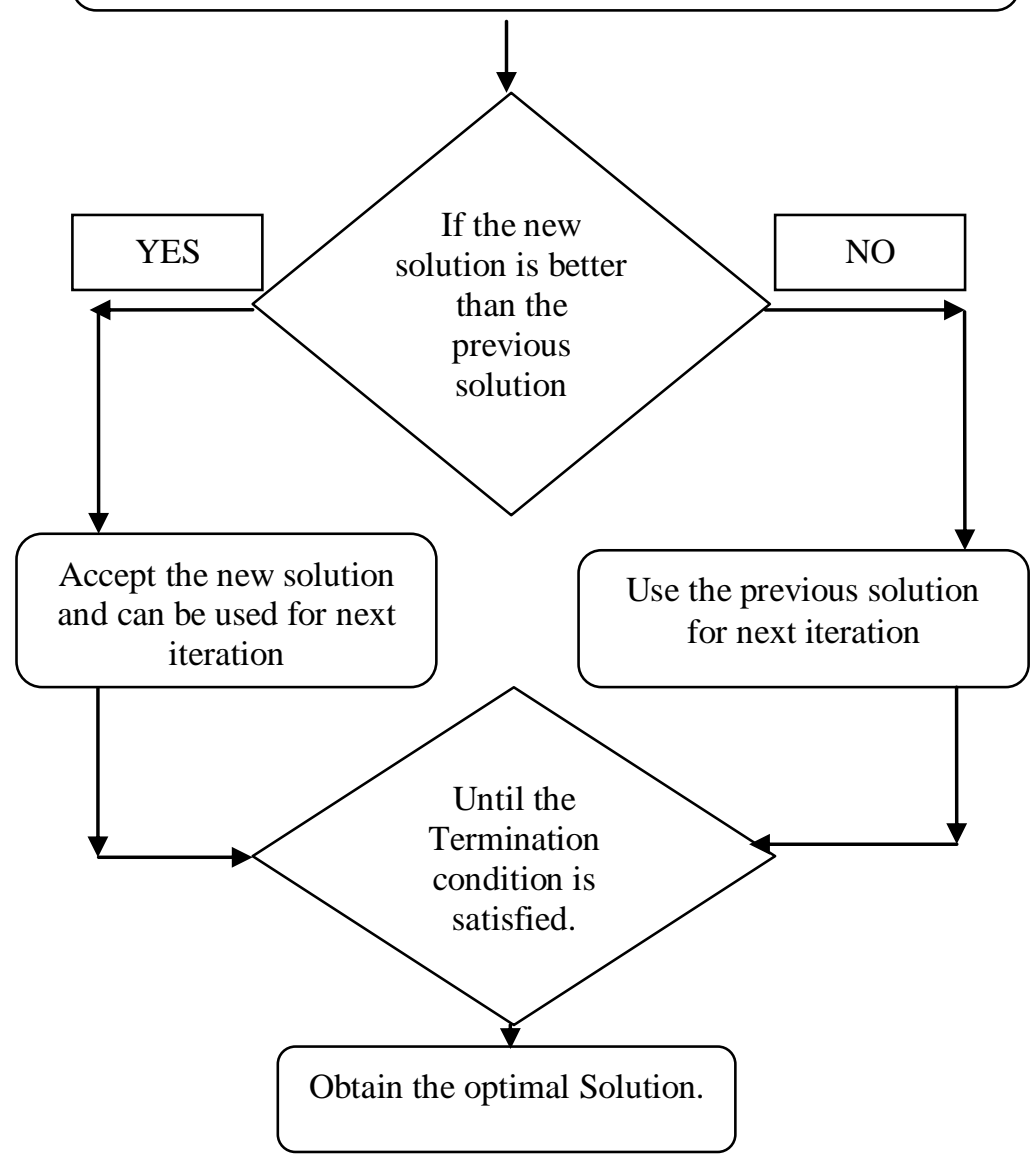

Fig.1: flowchart of Jaya based clustering techniques

Step 1: Initialize the population size and termination condition
First step size of the population is initialized and stopping condition for the process is set for clustering. The initial populations (p) have been created by using the parameters.

$$
\mathrm{P}=\left[\begin{array}{lll}
p_{1,1} & p_{1,2} & \ldots p_{1, n} \\
p_{2,1} & p_{2,2} & \ldots p_{2, n} \\
p_{m, 1} & p_{m, 2} & \ldots p_{m, n}
\end{array}\right]
$$

The design parameters are indicated as ' $\mathrm{n}$ ' and the candidate solutions is represented as ' $\mathrm{m}$ '.

Step 2: Identify the best and worst solution from candidate solutions

The next step is to identify the best solution for the particular iteration. If the best solution is better than the previous one, the best solution will be updated otherwise the previous solution is considered. Same process is repeated for the worst solution also.

$$
P_{k, j}=p_{j}^{\text {min }}+\operatorname{rand}(.)\left[p_{j}^{\text {max }}-p_{j}^{\text {min }}\right]
$$

Random produced number is indicated as rand (.) in the range of $(0,-1) \cdot p_{j}^{\max }$ - represents the upper boundaries. $p_{j}^{\min }$ represents the lower boundaries. $P_{k, j}$ - represents the membership function.

Step 3: Updation of Candidate solution based on best and worst solution obtained

The candidate solution is calculated by using the following equation. Here $\mathrm{i}, \mathrm{j}, \mathrm{k}$ represents the iteration parameters. $r_{1, k, i}$ and $r_{2, k, i}$ are uniformly distributed random number. The best and worst solution is updated in the candidate equation.

$$
p_{j, k, i}=p_{j, k, i}+r_{1, k, i}\left(p_{j, \text { best }, i}-\left|p_{j, k, i}\right|\right)-r_{2, k, i}\left(p_{j, \text { worst }, i}-\left|p_{j, k, i}\right|\right)
$$

\section{Step 4: Until the termination condition is satisfied}

The process of finding the best and worst solution will be continued until stopping condition (based on the fitness function) going to satisfy.

\section{Step 5: Finding the Optimal Solution}

Finally the optimal solution is calculated for the each iteration by repeating the above process.

\section{RESULTS AND DISCUSSIONS}

Different type and various grades of tumor are taken for the validation. The jaya perform quite better identifying the tumor and segmenting the other portions compared to the other conventional algorithm.


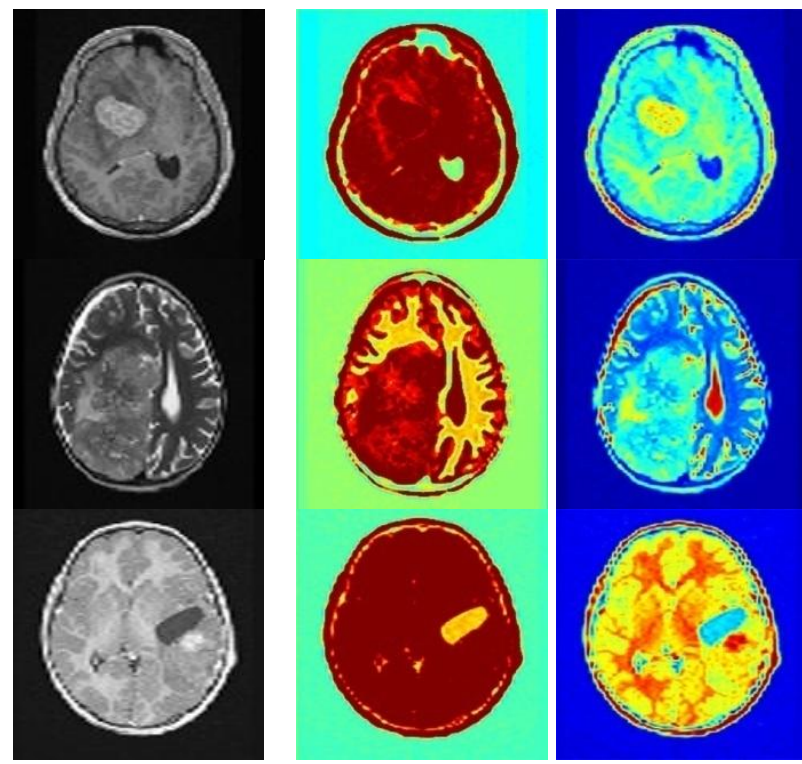

Table 1: MSE and PSNR Value for JAYA Algorithm

\begin{tabular}{|c|c|c|c|c|}
\hline \multirow[t]{2}{*}{ S.No } & \multicolumn{2}{|c|}{ MSE } & \multicolumn{2}{|c|}{ PSNR } \\
\hline & PSO & $\begin{array}{l}\text { JAYA } \\
\text { Algorithm }\end{array}$ & FCM & $\begin{array}{l}\text { JAYA } \\
\text { Algorithm }\end{array}$ \\
\hline 1 & 0.1978 & 0.1672 & 65.223 & 55.8985 \\
\hline 2 & 0.5098 & 0.1896 & 69.278 & 55.3532 \\
\hline 3 & 0.7812 & 0.0951 & 73.543 & 58.3498 \\
\hline 4 & 0.7914 & 0.079 & 74.108 & 59.1562 \\
\hline 5 & 0.7918 & 0.2204 & 74.123 & 54.6981 \\
\hline
\end{tabular}

\section{A. Mean square Error (MSE)}

MSE measures the square of error as an average .The variation between the estimated (gray scale input image) and expected output (demarcated image).

$$
\begin{gathered}
M S E(\text { Mean Square Error })=\frac{1}{p q} \sum_{i=\mathbf{0}}^{m-1} \sum_{\boldsymbol{j}=\mathbf{0}}^{n-1}[\boldsymbol{X}(\boldsymbol{i}, \boldsymbol{j})- \\
\boldsymbol{Y}(\boldsymbol{i}, \boldsymbol{j})]^{2}
\end{gathered}
$$

In the above equation the number of rows can be indicated as ' $I$ ' and the number of columns can be represented as ' $\mathrm{J}$ '. Less MSE values produces better results.

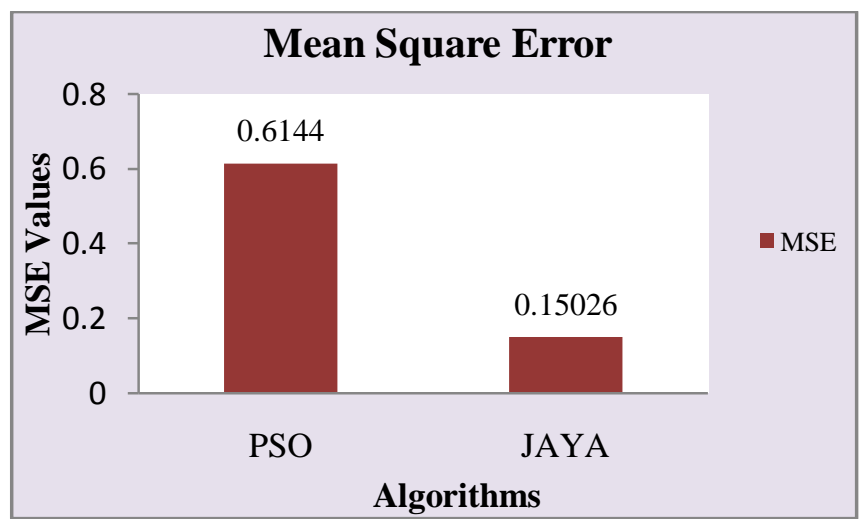

Fig.2.MSE value obtained for JAYA Algorithm

\section{B. PSNR(Peak signal to Noise ratio)}

PSNR denotes the range lies from the maximum possible value of pixel to influence of undignified noise that incurred the consistency of its slice.

$$
P S N R=10 \log _{10}\left(\frac{M A X_{i}^{2}}{M S E}\right)=20 \log _{10}\left(\frac{M A X_{i}}{\sqrt{M S E}}\right)=
$$

$20 \log _{10}\left(M A X_{i}\right)-10 \log _{10} M S E$

The segmented algorithm produces less MSE value when compared to the conventional algorithms. The less MSE values leads to produce more PSNR values.

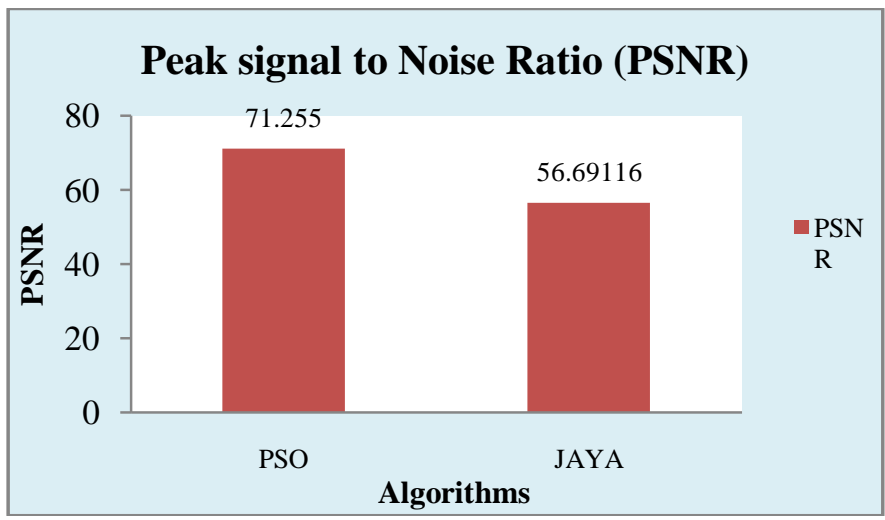

.Fig.3.PSNR value for JAYA algorithm

\section{CONCLUSION}

Identifying the various pathologies in medical image is a crucial task. The recommended Jaya algorithm identifies various types of tumors in MRI image and produces better results in terms of segmentation. This technique is compared with the existing technique particle swarm optimization (PSO) and produces better results in terms of MSE and PSNR values and the clustering is done by jaya algorithm by identifying the best and worst solutions and this process are repeated until the similar pixel will be clustered. Finally the optimal solutions are obtained using this techniques and jaya algorithm can be validated in more number of images by identifying different types of pathologies with different grades in future.

\section{REFERENCES}

[1] A Arnaud, F Forbes, N Coquery, N Collomb, B Lemasson, "Fully Automatic Lesion Localization and Characterization: Application to Brain Tumors Using Multiparametric Quantitative MRI Data," IEEE Transactions on Medical Imaging.pp. 1678 - 1689.

[2] A. Ahmadvand, M.R. Daliri, "Improving the runtime of MRF based method for MRI brain Segmentation," Applied Mathematics and Computation, 2015, pp. 808-818.

[3] A. Demirhan, I. Guler, "Combining stationary wavelet transform and self-organizing maps for brain MR image segmentation," Engineering Applications of Artificial Intelligence, 2011, pp. 358-367.

[4] B.N. Subudhi, V. Thangaraj, E. Sankaralingam, A. Ghosh, "Tumor or abnormality identification from magnetic resonance images using statistical region fusion based segmentation", Magnetic Resonance Imaging, 2016, pp.1292-1304.

[5] Egger, R. Opfer, C. Wang, T. Kepp, MP. Sormani. I Spies, M. Barnett, S. Schippling, "MRI FLAIR lesion segmentation in multiple sclerosis: Does automated segmentation hold up with manual annotation," Neuro Image: Clinical, 2017, pp. 264-270.

[6] H. Andac, U. Godze, K. Kutlay, E. Kayihan, K. Nadir, “ Tumor-Cut: Segmentation of Brain Tumors on Contrast Enhanced MR Images for Radio surgery Applications", IEEE transactions on medical imaging 2011,pp. 790-804.

[7] KY Lim, R Mandava, "A multi-phase semi-automatic approach for multisequence brain tumor image segmentation," Expert Systems with Applications.pp. 288-300. 
[8] Meiyan Huang,Wei Yang,Yao Wu,Jun Jiang,Wufan Chen,Brain Tumor Segmentation based on local Independent Projection-Based Classification, IEEE Transaction on Biomedical Engineering,Vol.61(2014) No.10.

[9] N. Thomos, N.V.Boulgouris, M.G. Strintzis, Optimized transmission of JPEG streams over wireless channels. IEEE Trans Image Process. 2006, pp. 54-67.

[10] S. Alagarsamy, K. Kamatchi, V. Govindaraj, A. Thiyagarajan, A Fully automated hybrid methodology using cuckoo-based fuzzy clustering technique for magnetic resonance brain image segmentation, International Journal of Imaging Systems and Technology,Vol. 27 (2017),pp. 317-332.

[11] S.Sairam, A.Soma vigneshwar.T.N.Ajith Kumar,A Saravanan, "Lesion Identification and Tissue Segmentation in Magnetic Resonance (MR) Image using Interval type based Clustering,'International Journal of Digital Communication and Networksc(IJDCN).pp.4501-4504.

[12] Selin Isoglu, Elif Isikci Koca, Dilek Goksel Duru, Comparative Multiple Sclerosis Lesion Segmentation in Magnetic Resonance Images, IEEE,2017.
[13] Sriparna Saha, Abhay Kumar Alok, Asik Ekbal, Brain image segmentation using semi-supervised clustering, Expert Systems with Applications, Vol 52 (2016) pp.50-63.

[14] V. Govindaraj, P.R. Murugan, A complete automated algorithm for segmentation of tissues and identification of tumor region in T1, T2, and FLAIR brain images using optimization and clustering techniques, International Journal of Imaging Systems and Technology,2014, pp. 313-325.

[15] RS Kamathe, KR Joshi, A novel method based on independent component analysis for brain MR image tissue classification into CSF, WM and GM for atrophy detection in Alzheimer's disease, Biomedical Signal Processing and Control,2018,pp.41-18.

[16] M Angulakshmi, GGL Priya, Brain tumour segmentation from MRI using superpixels based spectral clustering, Journal of King Saud University-Computer and Computer and Information Sciences,2018, https://doi.org/10.1016/j.jksuci.2018.01.009. 